\title{
Distribution and survival of leukemias in the mesoregion of the Potiguar West
}

\author{
Distribuição e sobrevida de leucemias na mesorregião do Oeste Potiguar \\ J. C. de Oliveira ${ }^{1 *}$; T. M. Torres ${ }^{2}$;W. O. Pereira ${ }^{1}$ \\ ${ }^{I}$ Departamento de Ciências Biomédicas, Laboratório de Bioquímica e Biologia Molecular, Universidade do Estado do \\ Rio Grande do Norte, 59607-360, Mossoró-Rio Grande do Norte, Brasil \\ ${ }^{2}$ Departamento de Ciências Biológicas e da Saúde, Laboratório de Engenharia Genética e Genômica e Proteômica, \\ Universidade Federal Rural do Semiárido, 59.625-900, Mossoró-Rio Grande do Norte, Brasil
}

*jessy_biotec@hotmail.com

(Recebido em 09 de janeiro de 2018; aceito em 16 de abril de 2018)

\begin{abstract}
In the mesoregion of the Potiguar West, Rio Grande do Norte, Brazil, literature concerning distribution and survival rates of leukemia in the population is sparse. This study intends to perform this analysis, exploring epidemiological data on patients, up to 100 years old, diagnosed between 2005 and 2014. In total, 183 patients with any type of leukemia were considered; acute myeloid leukemia was the most frequent (66 cases). Male patients were predominant (59\%) and most cases did not progress to death (59.1\%). In relation to survival, patients with acute myeloid leukemia presented less survival of 10 years after diagnosis, while patients with chronic lymphoid leukemia were most survival rates. Thus, it was possible to better characterize leukemia in this region, which is critical to identify possible risk factors and establish priorities on prevention, planning, management and evaluation of health services.

Keywords: cancer, epidemiology, death
\end{abstract}

Na mesorregião do Oeste Potiguar, Rio Grande do Norte, Brasil, a literatura sobre distribuição e sobrevida de leucemia na população é escassa. O presente estudo se propôs a fazer essa análise, explorando dados epidemiológicos em pacientes, de até 100 anos de idade, diagnosticados entre 2005 a 2014. Um total de 183 pacientes com algum tipo de leucemia foi encontrado, sendo a leucemia mielóide aguda (LMA) a mais frequente (66 casos). Houve predominância de pacientes do sexo masculino (59\%) e a maioria não evoluiu a óbito $(59.1 \%)$. Em relação à sobrevida, pacientes com leucemia mielóide aguda apresentaram menor sobrevida de 10 anos após o diagnóstico, enquanto pacientes com leucemia linfóide crônica apresentaram maior sobrevida. Nesse sentido, foi possível obter uma maior caracterização das leucemias nessa região, fundamental para definir possíveis fatores de risco e estabelecer prioridades na prevenção, planejamento, gerenciamento e avaliação dos serviços de saúde.

Palavras-chave: câncer, epidemiologia, óbito

\section{INTRODUCTION}

Today, cancer is an imminent health problem, accounting for one of the main causes of death in developed countries, and the second leading cause of death in developing countries [1]. About 12 million cancer cases and 7.6 million deaths caused by cancer were estimated for the year 2008 all over the world. The incidence rates of all types of cancer per 100,000 people were 202.8 for men and 164.4 for women. For leukemias, which are hematological cancers that occur in the tissues responsible for blood production, these rates were 5.8 for men and 4.3 for women [2].

The main forms of leukemia, according to the Brazilian Association of Leukemia and Lymphoma (ABRALE) are: Acute Myeloid Leukemia (AML), which is the most common type in adults; Chronic Myeloid Leukemia (CML), which affects mainly adults; Chronic Lymphocytic Leukemia (CLL), most often found in patients older than 55 years, and rarely affecting children; and Acute Lymphoblastic Leukemia (ALL), which is the most common form of leukemia in children. Acute leukemia exhibits rapid progression of the disease, and chronic is slowly progressive $[3,4,5,6]$. Leukemias are characterized for having high incidence, and often, low survival rates in today's society, it is the most common form of cancer in children and one of the most common forms in adults, according to the World Health Organization (WHO). The National 
Cancer Institute (INCA) predicted for the year of 2014 the occurrence of 9,370 new cases of leukemia in Brazil of these, 5,050 in men and 4,320 in women. In 2011, there were 6,187 deaths recorded; 3,277 of which were men and 2,910 women [7].

In Brazil, incidence rates of cancer vary widely according to the geographic region investigated. This variation may be due to different reasons, especially because of heterogeneous profiles of exposure to risk factors of the disease in populations from different regions of the country, as well as difficulties in diagnosis and initiation of treatment due to lack of resources [9]. Risk factors for leukemias are previous chemotherapy, genetic disorders caused by abnormal chromosomes, human $\mathrm{T}$ cell leukemia virus, myelodysplastic syndrome, exposure to radiation and occupational exposures to high levels of benzene or formaldehyde [8]. In the Northeast region, where our study fits, leukemia in men is the eighth most common cancer ( 4.15 per 100,000 people) and the tenth most frequent (3.40 per 100,000 people) in women, excluding nonmelanoma skin tumors. In Rio Grande do Norte $(\mathrm{RN})$ state, 160 new cases of leukemia are estimated in 2014 [7].

To the best of our knowledge, this is the first study in the state of RN, and is aimed at presenting the distribution and survival of leukemias in the population of the mesoregion of the Potiguar West, RN, Brazil, during 2005-2014; from epidemiological characterization data, since we have not yet observed works concerning this subject and cancer is an imminent health problem in this state. The study of epidemiological characteristics and mortality of leukemia will assist the monitoring of its trends and the assessment of the possible impacts on patient survival.

\section{MATERIAL AND METHODS}

Cross-sectional study performed using the review of a database obtained from a reference service in oncology in the state of RN: Oncology and Hematology Center of Mossoro (COHM). The information system collects data on all cancer patients treated at the hospital, which enables monitoring the progress of patients with malignant neoplasia treated at the institution.

The state of RN is subdivided into four mesoregions: Mesoregion of the Northeast Potiguar, Mesoregion Potiguar Central, Mesoregion of the East Potiguar and Mesoregion of the Potiguar West. This last is the largest among the four mesoregions, with more than $21,000 \mathrm{~km}^{2}$, representing more than $40 \%$ of the state area. There are five reference centers in the state of RN, but only the COHM serves Oeste Potiguar. Thus, the sample obtained for this study is representative of this region, considering that all patients treated at the reference center were included in the analyses [10, 11].

For this study, we considered all patients treated from January 2005 until December 2014 ( $\mathrm{n}=$ 183 patients) diagnosed with any form of leukemia (AML, CML, CLL and ALL), alive or deceased, up to 100 years old. The characteristics of the patients we considered were age, gender, region of origin (rural or urban), year of diagnosis (2005-2014), mortality and status vital (patient's clinical condition: alive and out of treatment, alive and in treatment, or deceased). Data were collected from October 2014 until January 2015. This study was approved by the Ethics Committee of the University of the State of Rio Grande do Norte (CEP / UERN), under the number 097/11. Descriptive measurements were used for statistical analysis. The patient survival time was estimated using the Kaplan-Meier survival function [12, 13, 14] (nonparametric method that allows comparison between different categories of a variable during the survival period for cancer) and log-rank $[15,16]$ (for assessing the statistical significance of the differences among the survival curves in the form of a chi-square test). The analysis was divided into men and women below and above 50 years of age. Values were considered statistically significant if $\mathrm{p}$ $<0.05$. Data analysis was performed using the programs Paleontological Statistics software package for education and data analysis 3.06 (Past) [16] and R [17].

\section{RESULTS AND DISCUSSION}

The medical records of patients attended at COHM and diagnosed from January 2005 to December 2014 were analyzed. In total, 183 patients with some form of leukemia (ALL, CLL, 
AML or CML) were considered, and the year with the highest number of cases was 2013, while the year with the lowest number of cases was 2007. The most frequent type of leukemia in these 10 years was the AML (66 cases) and least common type in the population studied was CLL (30 cases) as shown in Table 1.

Table 1: Distribution of leukemia cases in the time frame between 2005 and 2014 in the mesoregion of the Potiguar West, sorted by gender, age, year of diagnosis and status vital.

\begin{tabular}{|c|c|c|c|c|c|c|c|c|c|c|}
\hline \multirow{3}{*}{ Variables } & \multicolumn{10}{|c|}{ Form of leukemia } \\
\hline & \multicolumn{2}{|c|}{$\mathbf{A L L}^{\mathbf{a}}$} & \multicolumn{2}{|c|}{ CLL $^{b}$} & \multicolumn{2}{|c|}{$\mathrm{AML}^{\mathrm{c}}$} & \multicolumn{2}{|c|}{ CML $^{d}$} & \multicolumn{2}{|c|}{ Total } \\
\hline & $\mathbf{n}$ & $\%$ & $\mathbf{n}$ & $\%$ & $\mathbf{N}$ & $\%$ & $\mathbf{n}$ & $\%$ & $\mathbf{N}$ & $\%$ \\
\hline \multicolumn{11}{|l|}{ Gender } \\
\hline Female & 18 & 37,5 & 15 & 50,0 & 24 & 36,4 & 18 & 46,2 & 75 & 41,0 \\
\hline Male & 30 & 62,5 & 15 & 50,0 & 42 & 63,6 & 21 & 53,9 & 108 & 59,0 \\
\hline Total & 48 & 100,0 & 30 & 100,0 & 66 & 100,0 & 39 & 100,0 & 183 & 100,0 \\
\hline \multicolumn{11}{|l|}{ Age } \\
\hline 0 to 10 & 23 & 47,9 & 0 & 0,0 & 6 & 9,1 & 0 & 0,0 & 29 & 15,8 \\
\hline 11 to 20 & 12 & 25,0 & 0 & 0,0 & 7 & 10,6 & 1 & 2,6 & 19 & 10,4 \\
\hline 21 to 30 & 4 & 8,3 & 0 & 0,0 & 6 & 9,1 & 4 & 10,3 & 14 & 7,7 \\
\hline 31 to 50 & 5 & 10,4 & 1 & 3,3 & 16 & 24,2 & 13 & 33,3 & 36 & 19,7 \\
\hline 51 to 70 & 3 & 6,3 & 13 & 43,4 & 20 & 30,3 & 12 & 30,8 & 49 & 30,8 \\
\hline 71 to 100 & 1 & 2,1 & 16 & 53,3 & 11 & 16,7 & 9 & 23,1 & 36 & 19,7 \\
\hline Total & 48 & 100,0 & 30 & 100,0 & 66 & 100,0 & 39 & 100,0 & 183 & 100,0 \\
\hline
\end{tabular}

Year of diagnosis

\begin{tabular}{ccccccccccc}
\hline 2005 & 1 & 2,1 & 2 & 6,7 & 4 & 6,1 & 3 & 7,7 & 10 & 5,5 \\
\hline 2006 & 6 & 12,5 & 2 & 6,7 & 4 & 6,1 & 1 & 2,6 & 13 & 7,1 \\
\hline 2007 & 4 & 8,3 & 1 & 3,3 & 4 & 6,1 & 0 & 0,0 & 9 & 4,9 \\
\hline 2008 & 2 & 4,2 & 0 & 0,0 & 8 & 12,1 & 3 & 7,7 & 13 & 7,1 \\
\hline 2009 & 4 & 8,3 & 1 & 3,3 & 7 & 10,6 & 3 & 7,7 & 15 & 8,2 \\
\hline 2010 & 5 & 10,4 & 2 & 6,7 & 5 & 7,6 & 7 & 17,9 & 19 & 10,4 \\
\hline 2011 & 2 & 4,2 & 9 & 30,0 & 8 & 12,1 & 8 & 20,5 & 27 & 14,8 \\
\hline 2012 & 4 & 8,3 & 3 & 10,0 & 8 & 12,1 & 3 & 7,7 & 18 & 9,8 \\
\hline 2013 & 10 & 20,8 & 5 & 16,7 & 10 & 15,2 & 9 & 23,1 & 34 & 18,6 \\
\hline 2014 & 10 & 20,8 & 5 & 16,7 & 8 & 12,1 & 2 & 5,1 & 25 & 13,7 \\
\hline Total & 48 & 100,0 & 30 & 100,0 & 66 & 100,0 & 39 & 100,0 & 183 & 100,0 \\
\hline Statal
\end{tabular}

Status vital

\begin{tabular}{ccccccccccc}
\hline Alive, in treatment & 27 & 56,3 & 14 & 46,7 & 5 & 7,6 & 22 & 56,4 & 68 & 37,2 \\
\hline Alive, out of treatment & 7 & 14,6 & 9 & 30,0 & 16 & 24,2 & 8 & 20,5 & 40 & 21,9 \\
\hline Deceased & 14 & 29,2 & 7 & 23,3 & 45 & 68,2 & 9 & 23,1 & 75 & 40,9 \\
\hline Total & 48 & 100,0 & 30 & 100,0 & 66 & 100,0 & 39 & 100,0 & 183 & 100,0 \\
\hline
\end{tabular}

a: Acute lymphoblastic leukemia.

b: Chronic lymphocytic leukemia.

c: Acute myeloid leukemia.

d: Chronic myeloid leukemia.

During the 10-year period, the number of patients in COHM presented an increase tendency. The increase in cases may be associated with improvement of diagnostic techniques and better access of poorer people to treatments available through the National Health System (SUS). Was also observed that the majority of patients diagnosed with some form of leukemia was male 
(59.0\%). As to the age of patients at the time of diagnosis, most were aged between 51 and 70 years old (30.8\%). There was predominance of patients between 0 and 10 years old (47.9\%) with ALL, and patients between 71 and 100 years old (53.3\%) with CLL. Among those with AML most patients were aged between 51 and 70 years $(30.3 \%)$, and finally, the majority of patients with CML were between 31 and 50 years old (33.3\%). These results are consistent with the work of Redaelli (2004) [18], who shows an exponential increase in the incidence of CLL associated to age for both sexes. In addition, this author shows that this form of cancer happens in patients over 65 years old in the rate of 20.6 cases per 100,000 inhabitants per year, while in patients aged under 65 years old it is only observed in 1.3 cases per 100,000 inhabitants of the population [18, 19].

Most patients diagnosed in the period considered in this study $(59.1 \%)$ remained alive (in treatment or out of treatment). The year in which the highest number of deaths were the year 2013, with 16 deaths. In 2005 the fewest number of deaths were recorded, with one case. The joint analysis of the variables gender and age group notes that the majority of deaths occurred in males $(69.3 \%)$ and in the age group of 51 to 80 years old (45.33\%); data that were also found by other researchers $[5,20,21]$. The forms of leukemia with the most deaths were the AML, with 45 cases, and ALL, with 14 cases. CLL and CML showed fewer deaths, with 7 and 9 cases, respectively.

Unlike in adults, in whom epithelial tumors are predominant, the most common type of cancer in children include different forms of leukemia, lymphomas, tumors in the central nervous system, soft tissue, bone and kidney. Among the leukemia, the most common are acute forms, and among these, the ALL is the most common type, causing in total, in caucasian populations, from $75 \%$ to $80 \%$ of all leukemia cases, and having $85 \%$ survival rate in European countries and in the United States [22]. The CML is not common in children, and it rarely exceeds the proportion of 4\% [23]. ALL was the pediatric leukemia most frequent in Mossoro, which is in line with the global trend. In developed countries, infant mortality caused by leukemia decreased significantly in the last 30 years, although the incidence remained unchanged. In contrast, in developing countries, the incidence rate is maintained, but the infant mortality rates because of leukemia remain high $[9,24,25]$.

Regarding the city of origin of the patients, as shown in the map in Figure 1, most of the patients from the mesoregion of the Potiguar West were from urban areas (71.04\%), suggesting that the proximity to the reference center, located in Mossoro, favored the diagnosis. From cities such as Mossoro (responsible for most cases), Assu, Apodi, Patu, Sao Miguel, Areia Branca, Ipanguacu, Pau dos Ferros, Grossos, Alexandria, Itaja, Janduis, Campo Grande, Severiano Melo, Umarizal and Porto do Mangue. Patients from rural areas (28.96\%), in addition to the areas listed above, also came from Governor, Serra de Martins, Messias Targino, Afonso Bezerra, Serrinha dos Pintos and Sao Rafael. 


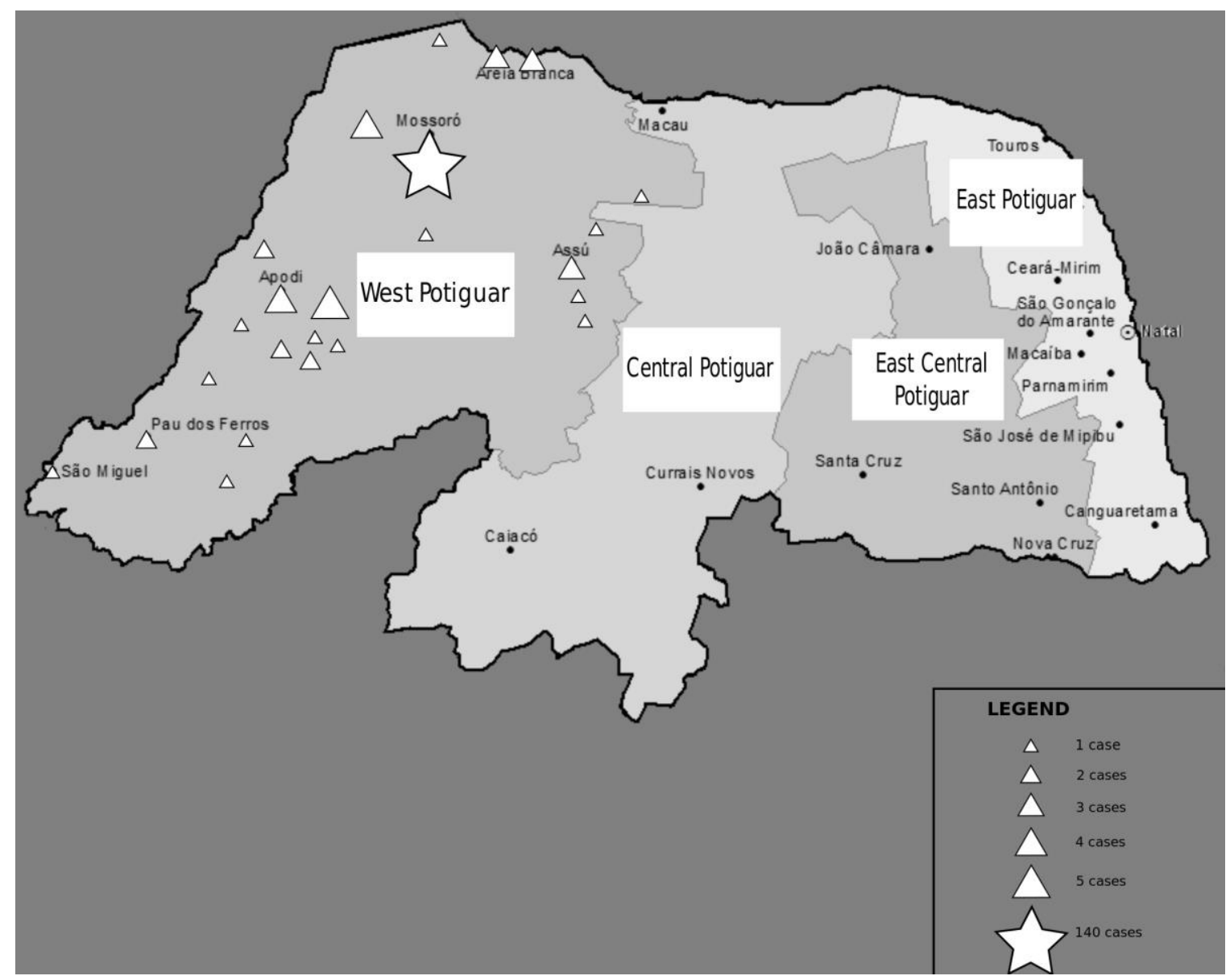

Figure 1: Map of the distribution of cases of leukemia between 2005 and 2014, in the mesoregion of the Potiguar West.

Another factor analyzed in this study was the patient survival. These analyses not only describe, as suggested by their name, whether patients live or die, but also other dichotomous outcomes such as setback in the disease status, infant weaning etc. In this work, survival is considered the time from the individual's entry into the study (date of diagnosis) until the occurrence of the event of interest death (due to leukemia) or halt in the observation (loss due to incomplete period of observation). The overall survival time was calculated in years [26].

In the Figure 2, was can observe that there is difference in behavior of women under 50 years and in men over 50 years old, with statistical significance (Figure 2-A and D). In groups of up to 50 years of age (Figure 2-A and C), women with AML presented survival less likely, while women with CLL a higher survival presented, with value of $p<0.05$. Men with up to 50 years of age and AML showed tendency to a lower survival, whereas men with CLL showed a tendency to a higher survival. In the groups above 50 years of age (Figure 2-B and D), women with AML presented a tendency to a lower survival, whereas women with ALL presented a tendency to a higher survival. Men over 50 years of age and ALL showed a smaller survival, whereas men with CML presented a higher survival, with value of $p<0.05$. Thus, patients diagnosed with CLL showed average survival time greater than the other forms of leukemia. Conversely, patients diagnosed with AML had average survival time shorter than patients with other forms of leukemia did. 

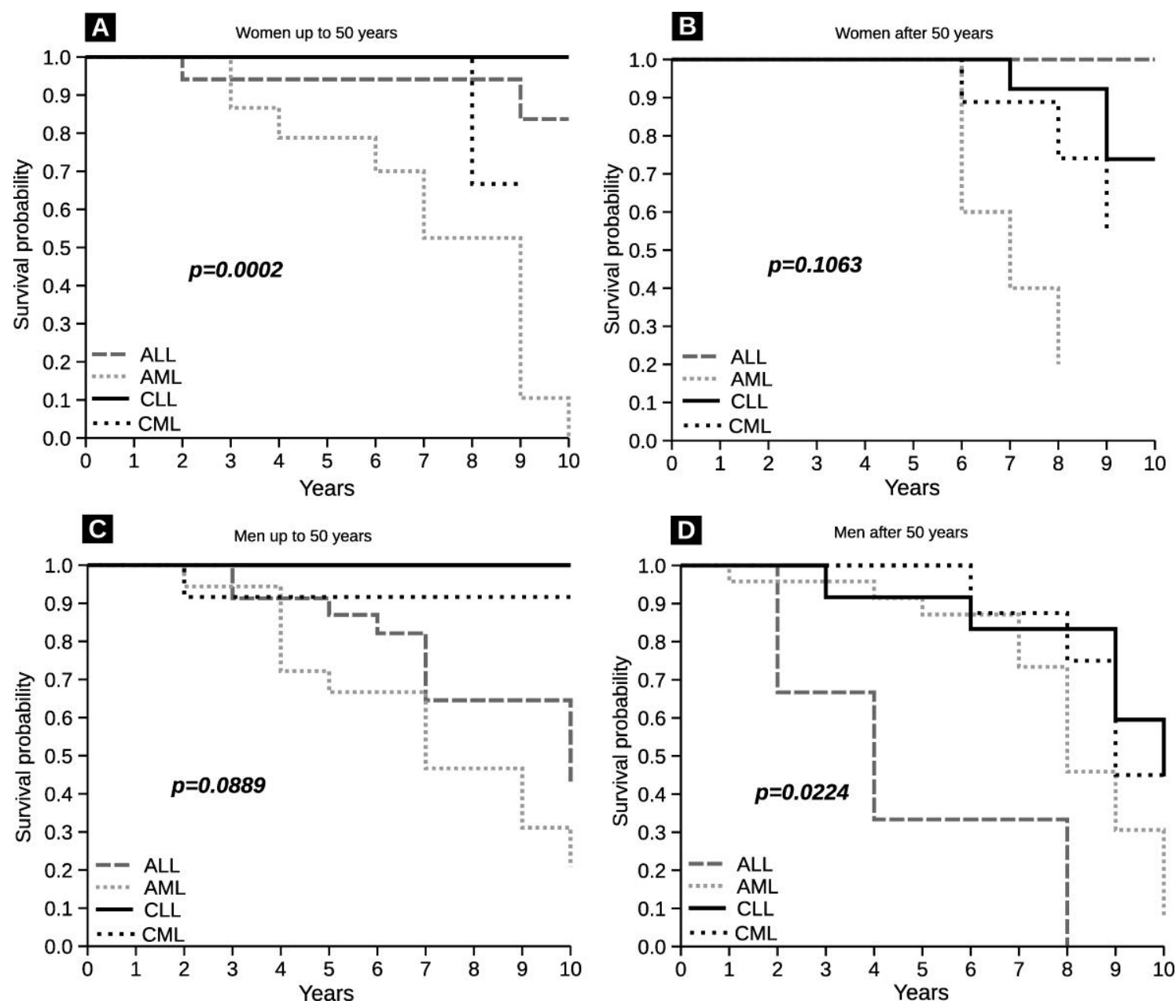

Figure 2: Kaplan-Meier curves analyzing the of survival (cases of leukemia between 2005 and 2014, in the mesoregion of the Potiguar West). Values were considered statistically significant if $p<0.05$.

An essential source for understanding the epidemiological profile of cancers in the population has been the study of the mortality pattern, even though information concerning only number of deaths does not allow real understanding of the magnitude of the problem, since there are various forms of cancer and, therefore, significant differences in mortality and survival rates for each one. This last parameter can be studied through population and hospital records, and controlled clinical studies. For the types of cancer with higher lethality rates, mortality allows an approximation of what would be the incidence, which does not occur with the types that have better prognosis. In this regard, access to information on incidence is critical to define the role of risk factors and establish priorities on prevention, planning, management and evaluation of health services [7]. Our analyses presented statistical significance, indicating that there is difference in survival rates between the groups. However, we emphasize the need for further studies integrating specialized centers of oncology and the SUS as a whole so that we can have a more accurate understanding of the impact of leukemia in our state.

Considering that the time between the first symptoms and the diagnosis of leukemia may influence the morbidity associated to the disease, some studies are being conducted aiming to reduce this time, which in developing countries is often long, with diagnosis happening in advanced stages of the disease. In northeastern Brazil, for example, despite the improvement in supportive care and the event-free survival rates in recent decades, these parameters are still worse than those found in hospitals in developed countries, even if the same chemotherapy protocol is used. Possible factors associated with this difference in prognosis, however, have not yet been elucidated and may happen due to the strong influence of socioeconomic and cultural factors, as well as the dynamics and structure of the health service [27, 28, 29]. 
The development of cancer is multifactorial and involves complex and long processes of genetic interactions and environmental factors in sequences of different stages. Several studies emphasize the importance of identifying risk groups for the triggering leukemia, especially in relation to exposure to various carcinogens. Risk factors for leukemia include genetic disorders caused by abnormal chromosomes, exposure to radiation and occupational exposure to high levels of benzene or formaldehyde, as well as previous chemotherapy. Smoking, radiation, myelodysplastic syndrome and other blood disorders are associated to AML, while some classes of drugs and Down syndrome are more directly linked to ALL [7, 30, 31, 32]. Knowledge concerning these factors is also important to determine preventive measures.

\section{CONCLUSION}

In our study, was observed that AML is the most common leukemia in the mesoregion of the Potiguar West and that least common type in the population studied was CLL. Was also observed that the majority of patients diagnosed with some form of leukemia was male and most patients diagnosed in the period considered in this study remained alive. The incidence of ALL was higher in younger people and of CLL, in the elderly, with significant results. Patients diagnosed with AML were less likely to be alive 10 years after diagnosis, while patients with CML were more likely. Thus, it was possible to analyze the distribution and survival for leukemia patients in the population of the mesoregion of the Potiguar West, and our data may serve as solid ground for planning, management and evaluation of health services in this area.

\section{REFERENCES}

1. Siegel R, Naishadham D, Jemal A. Cancer statistics, 2012. CA: Cancer J Clin. 2012 Jan-Fev;62(1):1029, doi:10.3322/caac.20138

2. Rajabli N, Naeimi-Tabeie M, Jahangirrad A, Sedaghat SM, Semnani S, Roshandel G. Epidemiology of leukemia and multiple myeloma in Golestan, Iran. Asian Pac J Cancer Prev. 2013 Apr;14(4):2333-6, doi:10.7314/APJCP.2013.14.4.2333

3. Associação Brasileira de Linfoma e Leucemia (ABRALE). O que é leucemia. Available from: Access on: May. 18, 2015.

4. Campo E, Swerdlow SH, Harris NL, Pileri S, Stein H, Jaffe ES. The 2008 WHO classification of lymphoid neoplasms and beyond: evolving concepts and practical applications. Blood. 2011 May;117(19):5019-32, doi:10.1182/blood-2011-01-293050

5. Tahmasby B, Marnani AB, Maleki M, Barouni M, Mousavi SH, Naseriyan B, Nazarnezhad M, Alizadeh A, Sabermahani A. Blood malignancies in Mazandaran Province of Iran. Asian Pac J Cancer Prev. 2013 Feb;14(2):1053-6, doi:10.7314/APJCP.2013.14.2.1053

6. Kampen KR. The discovery and early understanding of leukemia. Leuk Res. 2012 Jan;36(1):6-13, doi:10.1016/j.leukres.2011.09.028

7. Estimativa 2014: Incidência de Câncer no Brasil, Instituto Nacional de Câncer José Alencar Gomes da Silva, Coordenação de Prevenção e Vigilância (INCA). Rio de Janeiro; 2014.

8. Belson M, Kingsley B, Holmes A. Risk factors for acute leukemia in children: A review. Environ Health Perspect. 2007 Jan;115(1):138-145, doi:10.1289/ehp.9023

9. CDC. Trends in childhood cancer mortality - United States, 1990-2004. MMWR Morb Mortal Wkly Rep. 2007;56:1257-1261.

10. Instituto Nacional de Câncer (INCA). Tratamento pelo Sistema Único de Saúde. Available from: Access on: Feb. 07, 2016

11. Instituto Brasileiro de Geografia e Estatística (IBGE). Estados@. Available from: Access on: Mar. 29, 2016.

12. Kaplan EL, Meier P. Non parametric estimation from incomplete observation. J Am Stat Assoc. 1958 Jun;53(282):457-481.

13. Lee ET. Statistical Methods for Survival Data Analysis. 2nd Ed. New York: John Wiley \& Sons; 1992.

14. Kleinbaum DG. Survival Analysis: A Self Learning Text. New York: Springer; 1995.

15. Cox DR, Oakes D. Analysis of Survival Data. London: Chapman \& Hall; 1984.

16. Hammer $\varnothing$, Harper DAT, Ryan PD. PAST: Paleontological statistics software package for education and data analysis. Palaeontol Electron. 2001 Jun;4(1):1-9. 
17. Ihaka R, Gentleman R. R: a language for data analysis and graphics. J Comp Graph Stat. 1996;5(3):299314.

18. Redaelli A, Laskin BL, Stephens JM, Botteman MF, Pashos CL. The clinical and epidemiological burden of chronic lymphocytic leukemia. Eur J Cancer Care. 2004 Jul;13(3):279-87, doi:10.1111/j.1365-2354.2004.00489.x

19. Yamamoto M, Figueiredo VLP. Epidemiologia da leucemia linfocítica crônica e leucemia linfocítica crônica familiar. Rev Bras Hematol Hemoter [online]. 2005;27(4):229-232, doi:10.1590/S151684842005000400002

20. Longo D, Fauci A, Dennis K, Hauser S, Jamenson J, Loscalzo J. Harrison's Principles of Internal Medicine: 18th Edition; 2011.

21. Robert MK, Bonita MDS, Joseph SG, et al. Nelson Textbook of Pediatrics: 19th Edition. 2011;22:489490.

22. Ribeiro RC, Pui CH. Saving the children-improving childhood cancer treatment in developing countries. N Eng J Med. 2005 May;352:2158-2160, doi:10.1056/NEJMp048313

23. Luz JF. Perfil clínico-demográfico dos pacientes atendidos no serviço de oncologia pediátrica do hospital de clínicas de Porto Alegre: período de jan/2000 a dez/2010. [monografia de especialização] Porto Alegre, Universidade Federal do Rio Grande do Sul; 2011.

24. Bosetti C. Childhood cancer mortality in Europe, 1970-2007. Eur J Cancer. 2010 Jan;46(2):384-394, doi:10.1016/j.ejca.2009.09.011

25. Couto AC, Ferreira JD, Koifman RJ, Monteiro GTR, Pombo-de-Oliveira MS, Koifman S. Trends in childhood leukemia mortality over a 25-year period. J Pediatri. 2010 Jun;86(5):405-410, doi: 10.2223/JPED.2027

26. Bustamante-Teixeira MT, Faertein E, Latorre MR. Técnicas de análise de sobrevida. Cad Saude Publica [online]. 2002 May-Jun;18(3):579-594, doi:10.1590/S0102-311X2002000300003

27. Haimi M, Nahum P, Arush WB. Delay in diagnosis of children with cancer: a retrospective study of 315 children. J Pediatri Hematol Oncol. 2004;21(1):37-48, doi:10.1080/08880010490263579

28. Howards SC, Pedrosa M, Lins M, Pedrosa A, Pui C, Ribeiro RC, Pedrosa F. Establishment of a pediatric Oncology Program and outcomes of Childhood Acute Lymphoblastic Leukemia in a resource-Poor Área. JAMA. 2004 May;291(20):2471-5, doi:10.1001/jama.291.20.2471

29. Metzger ML, Howard SC, Fu LC, Peña A, Stefan R, Hancock ML, Zhang Z, Pui CH, Williams J, Ribeiro RC. Outcome of childhood acute lymphoblastic leukaemia in resource-poor countries. Lancet. 2003 Aug;362(9385):706-708, doi:10.1016/S0140-6736(03)14228-6

30. Wiemels J. Perspectives on the causes of childhood leukemia. Chem Biol Interact. 2012 Apr;196(3):5967, doi:10.1016/j.cbi.2012.01.007

31. Khatami M. Unresolved inflammation: 'immune tsunami' or erosion of integrity in immune-privileged and immune-responsive tissues and acute and chronic inflammatory diseases or cancer. Expert Opin Biol Ther. 2011 Nov;11(11):1419-1432, doi:10.1517/14712598.2011.592826

32. Seif AE. Pediatric leukemia predisposition syndromes: clues to understanding leukemogenesis. Cancer Genet. 2011 May;204(5):227-244, doi:10.1016/j.cancergen.2011.04.005 